\title{
Biofilm and Quorum Sensing in Archaea
}

\author{
MAŁGORZATA PAWLIKOWSKA-WARYCH, ${ }^{1}$ BEATA TOKARZ-DEPTU ${ }^{2},{ }^{2}$ \\ PAULINA CZUPRYŃSKA, ${ }^{3}$ WIESŁAW DEPTUŁA ${ }^{4}$
}

${ }^{1}$ Department of Microbiology, Faculty of Biology, University of Szczecin, Felczaka 3c, 71-412 Szczecin, Poland
2 Department of Immunology, Faculty of Biology, University of Szczecin, Felczaka 3c, 71-412 Szczecin, Poland
${ }_{3}^{3}$ Department of Microbiology, Faculty of Biology, University of Szczecin, Felczaka 3c, 71-412 Szczecin, Poland
${ }^{4}$ Nicolaus Copernicus University in Toruń, Faculty of Biological and Veterinary Sciences, Institute of Veterinary Medicine, Gagarina 7,
87-100 Toruń, Poland

Corresponding author, e-mail: beata.tokarz-deptula@usz.edu.pl

Keywords

Abstract

Archaea, biofilm, environment, quorum sensing

In the article, we presented a brief description of the Archaea, considering their structure, physiology and systematics. Based on the analysis of the literature, we bring closer the mechanism of biofilm formation, including extracellular polymeric substances as well as cellular organelles, such as archaella, pili and 'hami'. The method of forming a biofilm depends on the type of Archaea and the environment in which it naturally lives. We are also introducing the phenomenon of quorum-sensing, as a mechanism of communication of Archaea in the environment. This phenomenon corresponds to similar molecules as bacteria, namely acylated homoserines lactones, QS peptides, autoinducer-2 and -3 and others. In the case of biofilms and the occurrence of the phenomenon of quorum sensing, it can be concluded that these phenomena are very important for the life of Archaea. The phenomena described seem to be conservative, because both in Archaea and Bacteria are regulated by the same mechanisms.

\section{Biofilm i zjawisko "quorum sensing" u Archaea}

Słowa kluczowe

Streszczenie
Archea, biofilm, środowisko, quorum sensing

W artykule przedstawiamy opis Archaea, z uwzględnieniem ich budowy, fizjologii i systematyki. Na podstawie piśmiennictwa przybliżamy mechanizm tworzenia biofilmu wraz z pozakomórkowymi substancjami polimerowymi, a także typowe tylko dla archeonów organelle komórkowe, takie jak archaella, pili i „hami”. Metoda tworzenia biofilmu zależy od rodzaju Archaea i środowiska, w którym naturalnie żyje. Przybliżamy również zjawisko quorum-sensing, jako mechanizm komunikacji Archaea w środowisku. Za zjawisko to odpowiadają cząsteczki chemiczne podobne do tych u bakterii, a mianowicie acylowany lakton homoseryny, peptyd QS, autoinduktor-2 i -3 oraz inne. Opisywane zjawiska, zarówno tworzenie biofilmu jak i quorum-sensing są istotne dla życia archeonów. Opisane zjawiska wydają się konserwatywne, ponieważ zarówno u archeonów, jak i bakterii są regulowane przez te same mechanizmy. 


\section{Introduction}

Archaea form the domain, phylogenetically distinct from the other two domains, Bacteria and Eukarya (Staley, Caetano-Anolles, 2018). The concept of this domain was proposed after research published in the 70 years of the XX century by Woese and Fox (1977). They determining the phylogenetic similarity of microorganisms, using the $16 \mathrm{~S}$ rRNA nucleotide sequence and showed that methanogenic organisms are not bacteria, as previously believed (Forterre, Brochier, Philippe, 2002; Woese, Fox, 1977). Further investigation proved that some microorganisms from extreme ecological niches have so significant morphological, genetic, and physiological differences that they should constitute a separate taxonomic unit - domain (Forterre et al. 2002; Woese, Fox, 1977). The fact that such organisms occupied different environments, including extreme niches, which suggested their archaic origin, they have been referred to as Archaea (DeLong, 1998). Bergey's systematic (Boom, Castelholz, 2001) differentiates Archaea into two types: Euryarchaeota and Crenarchaeota (Boom, Castelholz, 2001; Forterre et al., 2002). After a result of isolation of rRNA from Yellowstone hot springs, the systematics of the Archaea has been extended by two not classification in any taxonomy range - Korarchaeota (Effenberger, Brzezińska-Błaszczyk, Wódz, 2014; Probst, Auerbach, Moissl-Eichinger, 2013) and Nanoarchaeota (Huber, Hohn, Stetter, Rachel, 2003; Probst et al., 2013). The last one is formed by small cocci-Nanoarchaeum equitans, bound to other Archaea from the Ignicoccus genus - isolated an undersea hydrothermal vent off the coast of Iceland (Huber et al., 2003; Probst et al., 2013). Furthermore, genetic analysis of mesophilic Archaea: Cenarchaeum symbiosum, Nitrosopumilus maritimus, and Nitrososphaera gargensis, of Crenarchaeota type, revealed they should be describe alone, and now are include in not classification in range Thaumarchaeota (Spang et al., 2010).

Archaea are present in various environments, including hot and cold waters, geysers, bottom sediments and soil (Boom, Castelholz, 2001; Effenberger et al., 2014; Huyhn, Verneau, Levasseur, Drancourt, Aboudharam, 2015). They can be halo-, acido-, and basophiles (Boom, Castelholz, 2001; Effenberger et al., 2014; Huyhn et al., 2015). They acquire energy from various inorganic compounds, such as sulphur compounds, metal ions, and organic compounds: saccharides and proteins (Boom, Castelholz, 2001; Forterre et al., 2002). Some Archaea of Euryarchaeota type are capable of producing methane (Bapteste, Brochier, Boucher, 2005). In the cellular membrane of all Archaea, there is glycerol-1-phosphate, to which branched isoprenoid chains are connected using ether bonds that are stronger than ester bonds. Such organisation of cellular membrane is of importance for such microorganisms' survival in extreme environments (Efenberger et al., 2014). In Haloquadratum walsabyi, additional external structures have been found, such as polysaccharide envelopes or halomucin capsules that help to survive in unfavourable conditions (lack of water) (Bapteste et al., 2005; Efenberger et al., 2014). Archeons, besides the extreme niches in which they occur and with which they are associated, are also a component of the plankton of the seas and oceans where they live in cooperation with environmental bacteria (DeLong, 1998). Archaea can also be a part of mammals microbiome, especially anaerobic, methanogenic genera (Methanobrevibacter, Methanobacterium, Methanosphaera), halophiles from the Halobacteriaceae family, thermophiles from Sulfolobus genus, as well as nitrification microorganisms from Nitrosphaera genus (Dridi, Didier, Drancourt, 2011; Matarazzo et al., 2012; Probst et al., 2013). 


\section{Biofilm in Archaea}

Similarly to bacteria, Archaea can form a biofilm, multicellular communities, formed on the surfaces or interfaces of materials both organic and inorganic nature. Biofilm microorganisms participates in the circulation of many elements in the environment, and allows for degradation of harmful compounds (Caderon et al., 2013). It has been described in psychrophiles, thermophiles, halophiles, and acidophilic Archaea, as well as in organisms oxidising ammonia, and producing methane (Bapteste et al., 2005; Caderon et al., 2013; Chudy, Jabłoński, Łukaszewicz, 2011; Fernandez, Diaz, Amilis, Sanz, 2008; Mayerhofer, Macario, Conway de Macario, 1992; Ozuolmez et al., 2015; Raskin, Rittmann, Stahl, 1996). In contrast to bacteria in Archaea, biofilm formation response to stress is exceptional, because this phenomenon has only been described in Sulfolobus species during intense UV radiation (Ajon et al., 2011; Fröls, 2013) and in Haloferax volcanii exposure to lethal concentrations of biocidal compounds (Megaw, Gilmore, 2017). Similarly as in bacteria, in Archaea first steps in biofilm formation is adhere to the surface where the biofilm will be formed and then secretion of polymeric compounds outside cells (Caderon et al., 2013; Fröls, 2013). As regards extracellular polymeric substances (EPS), they have been found to include: polysaccharides, eDNA (extracellular DNA), glycosylated proteins, lipids, and enzymes specific to this group of microorganisms (Flemming, Wingender, 2010). Especially this element of biofilm being recorded in thermo-acidophilic Sulfolobus (S.) acidocaldarius, S. solfataricus, and $S$. tokodai (Jachlewski et al., 2015; Koch, Rudolph, Moissl, Huber, 2006). It was also evidenced that the most frequent component of polymeric compounds are the monosaccharides that glycosylate proteins (Koerdt et al., 2012; Zolghard et al., 2010), which would point to their role as nutrient storage, similarly as in the case of bacteria (Zolghard et al., 2010). As regards $S$. solfataricus, genes were found that are in charge of biodegradation of saccharides with $\beta$-galactosidase $(\operatorname{LacS})$ and $\alpha$-mannosidase ( $S s \alpha-m a n$ ) activity, and it was proven that the products of such genes can condition EPS volume in biofilm, and probably control the saccharide volume in biofilm matrix (Koerdt et al., 2012). In biofilm matrix of halophiles from Halobacterium, Haloferax, and Halorobrum genera found glycosylated compounds and eDNA (Fröls, Dyall-Smith, Pfeifer, 2012) whereas in hyper-thermophile Thermococcus litoralis, biofilm matrix was formed of polysaccharide - mannan (Rinker, Kelly, 1996).

In formation of Archaea biofilm a major role belongs to extracellular organelle, such as archaella, pili - showing a different structure from the bacterial one, cannulae, 'hami' (Efenberger et al., 2014; Ng, Zolghadr, Driessen, Albers, Jarrell, 2008) and extracellular polymeric substances (EPS) (Flemming, Wingender, 2010). Archaella are in charge of motion, analogically to bacterial flagella. Archaellum's filament forms a right-hand helix with the diameter of 10-14 nm (Lassak et al., 2012), although their structure reveals greater phylogenetic affinity to the bacterial type IV pili than flagella (Bardy, Jarrel, 2003). The method of secreting proteins of bacterial and archaella's pili is similar. Archaella in Archaea are coded by the fla gene family (Bardy, Jarrel, 2003; Szabo et al., 2007). Apart from allowing motion and binding microorganisms to abiotic surfaces, archaella also play a role in the contact among such microorganisms (Lassak et al., 2012; Ng et al., 2008). Pili in Archaea are built of two sub-units that may form a helix or a ring (Pohlschröder, Esquivel, 2015; Wang, Yu, Ng, Jarrell, Egelman, 2008). There are two types of such organella, namely Ups pili and Aap pili. Ups pili occur in Sulfolobus (S.) solfataricus in the case of intense UV radiation, and participating in formation of cell batteries to accelerate DNA repair (Wang et al., 2008). Aap pili have been reported in S. acidocaldarius, which Archaea occur in environments with large volumes of nutrients, and their role is related to cell adhesion to various surfaces 
and biofilm maturation (Wang et al., 2008). Cannulae are organella characteristic exclusively of Archaea from Pyrodictium genus, they participate in cell adhesion and forming biofilm (Horn, Paulmann, Kerlen, Junker, Huber, 1991; Montgomery, Charlesworth, LeBard, Visscher, Burns, 2013; Nickell, Hegerl, Baumeister, Rachel, 2003). Cannualae are built by three glycoproteins with the structure of empty tubes branching from peri-plasmatic space and they reveal resistance to high temperatures (Horn et al., 1991; Nickell et al., 2003). Cannulae have also been observed after cell division, when the daughter cells are connected by them; by multiple repetition, a colony of cells looks like connected with a network. This suggests that such organella can take part in the transmission of nutrients and the genetic material (Horn et al., 1991; Montgomery et al., 2013; Nickell et al., 2003). 'Hami' have been described for Altiarchaeum hamiconexum (formely SM1 euryarchaeon), that inhabit cold mashes in Bavaria that are rich in sulphur compounds (Hennenberger, Moissl, Amann, Rudolph, Huber, 2006; Moissl, Rachel, Briegel, Engelhardt, Huber, 2005). 'Hami' are helical tabs of about 1-3 $\mu \mathrm{m}$ with spikes spaced about every $46 \mathrm{~nm}$ and ended with three hooks. Such structures resemble a barbed wire have resistant to mechanical, thermal, and chemical agents, and was responsible for Archaea adhere to different surface (Hennenberger et al., 2006; Moissl et al., 2005). In Archaea inhabiting the natural environment, biofilm is popular and principally refers to Archaea from Euryarchaeota and Crenarchaeota types, formed together with bacteria (Fröls, 2013; Hennenberger et al.; 2006; Jachlewski et al., 2015; Koch et al., 2006; Koerdt, Godake, Berger, Thormann, Albers, 2010; Lapaglia, Hartzell, 1997; Rinker, Kelly, 1996; Schopf, Wanner, Rachel, Wirth, 2008; Schrenk, Kelley, Delaney, Baross, 2003; Szabo et al., 2007). In water reservoir sediments and densified water was evidenced that methanogenic Archaea, belonging to Euryarchaeota forming biofilm with bacteria that reduce sulphates from Desulfovibrionaceae and Desulfobacteriaceae. This organisms proliferated in the presence of acetates, which are a substrate for their energy (Ozuolmez et al., 2015; Raskin et al., 1996). The microorganisms occur anaerobic environment of biological wastewater treatment plants, rich in calcium and magnesium ions (Caderon et al., 2013; Chudy et al., 2011; Fernandez et al., 2008; Mayerhofer et al., 1992). Aggregates of Archaea form on solid waste particles, and can float freely on wastewater surface, or adhere to different materials (eg. polystyrene or glass). Apart from methanogenic microorganisms of Euryarchaeota type, such biofilm is also formed by such bacteria as Bacillus sp., Aeromonas sp., Acinetobacter sp., Delftia sp., Comanomonas sp., Chryseobacterium sp., Trichococcus sp., and Nostocoida sp. (Caderon et al., 2013; Chudy et al., 2011; Fernandez et al., 2008; Mayerhofer et al., 1992). A biofilm was also reported in Ferroplasma acidarmanus, Euryarchaeota type, formed together with Leptospirillum sp. bacteria, found in acid leachate from Iron Mountain mine, Michigan (USA) (Baker-Austin, Potrykus, Wexler, Bond, Dopson, 2010). As regards biofilm formed by Ignisphaera aggregans and Pyrobaculum sp. of Crenarcheota type, isolated from the slide of a pool located near hot springs in New Zealand, it was found that the biofilm can be formed as aggregates, particularly with polysaccharides present in subgrade, as they form the source of carbon (Niederbeger, Götze, McDonald, Ronimus, Morgan, 2006). In case of Nitrosopumilus maritimus was reported that bioflim formed with bacteria of Nitrosomonas and Nitrospira genera on a polyvinyl trickling filter in marine aquaculture system (Foesel et al., 2008). If was revealed that, in the process of adhesion to glass plates, Methanopyrus (M.) kandleri and Pyrococcus (P.) furiosus form multilayer biofilms using pili, and probably also archaeallum (Rinker, Kelly, 1996). Thermococcus (T.) litoralis and $P$. furiosus, however, together with other hyperthermophiles, form biofilm on glass and polycarbonate plates, although the time of biofilm formation depends on the presence of maltose or yeast extract (Rinker, Kelly, 1996). In geothermal conditions, namely in hot springs and hydrothermal 
vents in seas, biofilm has also been reported in hyper-thermophile M. kandleri and T. litoralis from Euryarchaeota, which form biofilm with P. furiosus (Rinker, Kelly, 1996; Schopf et al., 2008). Biofilm mixed with bacteria is also formed by Euryarchaeota from Methanosarcinales, Thermococcales, Archaeoglobales orders, and Archaea from Thermoproteales order, Cranarchaeota type, isolated from hydrothermal vents with high content of sulphur compounds (Schrenk et al., 2003). Organisms using filaments can form aggregates on mineral deposits largely formed of sulphur compounds (Schrenk et al., 2003). It was observed that hyperthermophiles from Archaeoglobus fulgidus, belonging to Euryarchaeota type and inhabiting seals, is the only representatives of Archaea that forms biofilm composed of polysaccharides, proteins, and metal ions. This biofilm is formed after activation of stress factors, such as UV radiation, temperature change, $\mathrm{pH}$ decrease, or increased concentration of metals and chemotherapeutic agents (Fröls, 2013; Lapaglia, Hartzell, 1997; Ng et al., 2008). The biofilm formation has also been observed in such Archaea as: Halobacterium salinarum, Haloferax volcanii, Halorubrum lacusprofundi, and the Halohasta litchfieldiae (strain DL24) (Fröls et al., 2012). Biofilm of Halohasta litchfieldiae is formed on abiotic surfaces by archaeallum and EPS, principally eDNA and glycosylated organic compounds, and has the structure of a single layer or aggregate structure (Haloferax volcanii, or Halorubrum lacusprofundi) (Fröls, 2013). Also psychrophilic Archaea of Euryarchaeaota type, Altiarchaeum hamiconexum, in aquatic environment with high concentration of sulphuric compounds forming biofilm together with bacteria Thiothrix sp. on polyethylene strands using 'hami' (Bird, Baker, Probst, Podar, Lloyd, 2016; Hennenberger et al., 2006). The biofilm is characterised with a structure resembling a pearl necklace, where the external layer is formed by bacteria, while the internal one by Archaea bound to the strand (Hennenberger et al., 2006). Biofilm has also been reported in Archaea of Crenarchaeota type, including S. solfataricus, S. acidocaldarius, and $S$. tokodai species that inhabit geothermal areas with volcanic activity (Jachlewski et al., 2015; Koerdt et al., 2012, Koerdt et al., 2011; Szabo et al., 2007). The biofilm is formed using archaellum and pili, and with saccharide secretion. Moreover, in laboratory conditions, biofilm formation on pilus-dependent way, upon UV exposure was found $S$. solfataricus and $S$. acidocaldarius (Jachlewski et al., 2015; Koerdt et al., 2012; Pohlschröder, Esquivel, 2015; Szabo et al., 2007). Other thermo-acidophiles - Metallosphaera sedula from Crenarchaeota type, with the capacity of iron compound oxidation, forming biofilm as aggregates using archaellum, on surfaces containing iron sulphide. The biofilm formation process probably involves EPS, glycosylated using galactose or ramnose (Auernik, Maezato, Blum, Kelly, 2008).

\section{Quorum sensing in Archaea}

Quorum sensing (QS) is a cell to cell signaling mechanism among bacterial cells which coordinate their activities. In this mechanism many various species-specific QS signaling molecules (QSSMs) are used. Acylated homoserines lactones (AHLs), QS peptides (QSPs), autoinducer-2 (AI-2), diketopiperazines (DKPs), autoinducer-3 (AI-3) and another are included for these molecules (Rajput, Gupta, Kumar, 2015; Rajput, Kaur, Kumar, 2016). The phenomenon, both in bacteria and Archaea is conditioned with genes that allow their adaptation and survival in the unfavourable environment, such as temperature shock, lack of nutrients, drastic changes to salinity and $\mathrm{pH}$, and the presence of chemotherapeutical agents (Bassler, 2002; Megaw, Gilmore, 2017; Montgomery et al., 2013; Paggi, Martone, Fuqua, De Castro, 2003). In the case of the Bacteria domain, the QS mechanism can be divided into three types depending on autoinducer-1 (AI-1), peptide and autoinducer-2 (AI-2), wherein systems based on AI-1 and AI-2 are common 
in Gram-negative bacteria, and peptide based system occurs in Gram-positive bacteria (Barriuso, Martinez, 2018; Kaur, Capalash, Sharma, 2018; Montgomery et al., 2013). The systems AI-1 and AI-2 use AHLs (acylated homoserine lactones) as inducers, where system AI-1 use LuxR and LuxI proteins, and system AI-2 use proteins like LuxS, LuxP, LsrB, RosB, Pfs and SAH hydrolase (Abisado, Benomar, Klaus, Dandekar, Chandler, 2018; Montgomery et al., 2013). In AI-1 system, LuxI produce N-3-oxo-hexanoyl-homoserine lactone, which specifically binds to LuxR, which is a factor that activates luxCDABEG operon, which contains for examples the genes enables bioluminescence (Abisado et al., 2018) and the genes that condition bacterial survival in the new conditions (Bassler, 2002; Myszka, Czaczak, 2010). Most of bacterial AHLs are produced from $S$-adenosylmethionine (SAM) and an acylated acyl carrier protein (ACP) from the fatty acid biosynthesis pathway (Abisado et al., 2018). In Gram-positive bacteria, the inductor function is held by short oligopeptides formed as a result of processing longer protein chains secreted to the environment via active transport. When the concentration of such compounds (inductors) reaches a critical level, this is recognised by a specific receptor: histidine kinase, and a number of reactions occur aimed at formation of a regulatory protein that would affect the expression of target genes (Jaworski, Serwecińska, Stączek, 2005). In the case of Archaea, a phenomenon analogical to the bacterial QS system was reported for haloalkaliphilic archaeon Natronococcus occultus (Euryarchaeota type), where it was observed that together with the increase in culture density and exhaustion of nutrients in the medium, the volume of proteases secreted outside the cells increases. Research focused at identifying this phenomenon did not manage to point to AHL-like self-inductors due to their sensitivity to alkaline $\mathrm{pH}$ and the presence of short chains of such particles (Montgomery et al., 2013; Paggi et al., 2003). Analogical research referred to Natrialba magadii, of Euryarchaeota type, which occupies the same ecological niches as Natronococcus occultus and revealed that AHL-like particles can act as inductors, but only when their chain is long enough for the inductor to remain stable in alkaline environment (Paggi et al. 2003; Paggi, Madrid, D’Alessamdro, Cerletti, De Castro, 2010). Communication among Archaea cells, using an AHL-like system, was at the first time evidenced for Methanosaeta harundinacea (Euryarchaeota type) where three compounds were detected: N-carboxyl-decanoyl-homoserin lactone, N-carboxyl-dodecanoyl-homoserine lactone and N-carboxyl-tetradecanoyl-homoserine lactone (Zhang et al., 2012). Those compounds are formed as a result of activation of fill-filR genes being orthologs of the bacterial luxI-luxR system (Zhang et al., 2012). Research focused on the QS system in Methanosaeta harundinacea has proved that the system is responsible for filament production and changes to carbon metabolism (Li et al., 2015; Montgomery et al., 2013). It was also evidenced that cyclo-(L-prolyl-L-valine), belonging to the diketopiperazines (DKPs) can act as signal particles in QS phenomenon in Haloterrigena hispanica (Euryarchaeota type), unrelated to the typical bacterial communication system (Tommonaro, Abbamondi, Iodice, Tait, De Rosa, 2012). In the culture of those halophiles, five variants of diketopiperasines (DKPs) particles were extracted, which can participate in the adaptation of such Archaea in extremely salinated environment and, together with bacterial AHL, in the communication of mixed cultures in the biofilm (Tommonaro et al., 2012). Also in halophilic strain SK-6, belonging to Haloterrigena genus, compounds of diketopiperazines was found (Abed, Gotthard, Champion, Chabriere, Elias, 2013). The lactonase VmoLac, phosphotriesterase-like lactonase (PLL) was reported in hyperthermophile Vulcanisaeta moutnovskia (Crenarcheota type) (Hiblot et al., 2013). This lactonase hydrolyze various lactones, including AHLs, what suggest that could be involved in QS in this archaeon (Hiblot, Bzdrenga, Champion, Chabriere, Elias, 2015). Also in Pyroccocus furiosus, hypertermophilic archaeon, was observed that temperature mediates autoinducer-2 (AI-2) 
formation, despite lacking the enzymes Pfs and LuxS (Nichols, Johnson, Chou, Kelly, 2009). It evidence, that Archaea use QS mechanism typical for bacteria, but using different molecules to activate the signalling pathways (Montgomery et al., 2013; Nichols et al., 2009). In the last research was found that only SAH hydrolase (S-adenosyl-L-homocysteine hydrolase) and Pfs (5'methylthioadenosine/S-adenosylhomocysteine nucleosidae), a part of AI-2 system are presence in termophiles Archaea (Kaur et al., 2018).

\section{Conclusion}

Archaea, are microorganisms that inhabit very different environments, from ecological niches as. hypersaline, hot and cold waters, marine sediments, soil, and even mammalian microbiome. They are known from over 40 years but still new facts are discovered, e.g. about biofilm formation and cell-to-cell signaling mechanism. It is know that Archaea's biofilm is formed by polymeric particles secreted by such microorganisms to the biological membrane matrix, which sustains interactions among organisms. Archaea form biofilm together with bacteria, thus they participate in the transformation of various compounds and play a major role in the environment, such as biological wastewater treatment processes. Communication mechanism for organisms in the domain is similar to the bacterial quorum sensing, but occurring using a little bit different signal particles. This facts about the Archaea group reveal new data in the area of their physiology.

\section{References}

Abed, R.M.M., Dobretsov, S., Al-Fori, M., Gunaskera, S.P., Sudesh, K., Paul, V.J. (2013). Quorum-sensing inhibitory compounds from extremophilic microorganisms isolated from a hypersaline cyanobacterial mat. J. Indust. Microbiol. Biotechnol., 40, 759-772.

Abisado, R.G., Benomar, S., Klaus, J.R., Dandekar, A.A., Chandler, J.R. (2018). Bacterial quorum-sensing and microbial community interactions. mBio, 9, e02331-17.

Ajon, M., Fröls, S., van Wolferen, M., Stoecker, K., Teichmann, D., Driessen, A.J.M., Grogan, D.W., Albers, S.-J., Schleper, C. (2011). UV-inducible DNA exchange in hyperthermophilic archaea mediated by type IV pili. Mol. Microbiol., 82, 807-817.

Auernik, K., Maezato, Y., Blum, P., Kelly, M. (2008). The genome sequence of the metal-mobilizing, extremaly thermoacidophilic archeon Metallosphaera sedula provides insights into bioleaching-asociated metabolism. Appl. Environ. Microbiol., 74, 682-692.

Baker-Austin, C., Potrykus, J., Wexler, M., Bond, P., Dopson, M. (2010). Biofilm development in the extremaly acidophilic archaeon Ferroplasma acidarmanus Ferl. Extremophiles, 14, 485-491.

Bapteste, E., Brochier, C., Boucher, Y. (2005). Higher-level classification of the Archaea: evolution of methanogenesis and methanogens. Archaea, 1, 353-363.

Bardy, S., Jarrel, K. (2003). Cleavage of preflagellins by an aspartic acid signal peptidase is essential for flagellation in the archeon Methanococcus voltae. Mol. Microbiol., 50, 1339-1347.

Barriuso, J., Martinez, M.J. (2018). In silico analysis of the quorum-sensing metagenome in environmental biofilm samples. Front. Microbiol. DOI: 10.3389/fmcb.2018.01243.

Bassler, B. (2002). Small talk: cell-to-cell communication in bacteria. Cell, 109, 421-424.

Bird, J.T., Baker, B.J., Probst, A.J., Podar, M., Lloyd, K.G. (2016). Culture independent genomic comparisons reveal environmental adaptations for Altiarchaeales. Front. Microbiol. DOI: 10.3389/fmicb. 2016.01221. 
Boom, D.R., Castenholz, R.W. (eds.) (2001). Bergey's Manual of Systematic Bacteriology. Vol. 1: The Archaea and the deeply branching and phototrophic Bacteria. New York: Springer.

Caderon, K., Gonzalez-Martinez, A., Gomez-Silvan, C., Osorio, F., Rodelas, B., Gonzalez-Lopez, J. (2013). Archaeal diversity in biofilm technologies applied to treat urban and industrial wastewater: recent advances and future prospects. Int. J. Mol. Sci., 14, 18572-18598.

Chudy, D., Jabłoński, S., Łukaszewicz, M. (2011). Determining the dynamics formation of biofilm deposits by microorganisms methanogenic fluorescence microscopy and dark field using image analysis. Acta Sci. Pol. - Biotechnologia, 10, 17-28.

DeLong, E. (1998). Everything in moderation: Archaea as 'non-extremophiles'. Curr. Opin. Gen. Develop., 6, 649-654.

Dridi, B., Didier, R., Drancourt, M. (2011). Archaea as emerging organisms in complex human microbiomes. Anaerobe, 17, 56-63.

Efenberger, M., Brzezińska-Błaszczyk, E., Wódz, K. (2014). Archaeons - still unknown microorganisms (in Polish). Post. Hig. Med. Dośw., 68, 1452-1463.

Fernandez, N., Diaz, E., Amilis, R., Sanz, J. (2008). Analysis of microbial community durning biofilm development in anerobic westwater treatment reactor. Microbiol. Ecol., 56, 121-131.

Flemming, H., Wingender, J. (2010). The biofilm matrix. Nature Rev. Microbiol., 8, 623-633.

Foesel, B., Gieseke, A., Schwermer, C., Stief, P., Koch, L., Cytryn, E., de la Torre, J., van Rijn, J., Minz, D., Drake, H., Schramm, A. (2008). Nitrosomonas Nm143-like ammonium oxidizers and Nitrospira marina-like nitrate oxidizers dominate the nitrifier community in a marine aquaculture biofilm. FEMS Microbiol. Ecol., 63, 192-204.

Forterre, P., Brochier, C., Philippe, H. (2002). Evolution of the Archaea. Theoret. Pop. Biol., 61, 409-422.

Fröls, S., Dyall-Smith, M., Pfeifer, F. (2012). Biofilm formation by haloarchaea. Environ. Microbiol., 14, 3459-3174.

Fröls, S. (2013). Archaeal biofilms: widespread and complex. Bioch. Soc. Trans., 41, 393-398.

Hennenberger, R., Moissl, C., Amann, T., Rudolph, C., Huber, R. (2006). New insights into the lifestyle of the cold-loving SM1 Euryarchaeon: natural growth as monospecies biofilm in the subsurface. Appl. Environ. Microbiol., 72, 192-199.

Hiblot, J., Gotthard, G., Champion, C., Chabriere, E., Elias, M. (2013). Crystallization and preliminary X-ray diffraction analysis of the lactonase VmoLac from Vulcanisaeta moutnovskia. Acta Cryst., $F, 69,1235-1238$.

Hiblot, J., Bzdrenga, J., Champion, C., Chabriere, E., Elias, M. (2015). Crystal structure of VmoLac, a tentative quorum quenching lactonase from the extremophilic cranarchaeon Vulcanisaeta moutnovskia. Sci. Rep. DOI: 10.1038/srep08372.

Horn, C., Paulmann, B., Kerlen, G., Junker, N., Huber, H. (1991). In vivo observation of cell division of anaerobic hyperthermophiles by using a high-intensity dark-field microscope. J. Bacteriol., 181, 5114-5118.

Huber, H., Hohn, M., Stetter, K., Rachel, R. (2003). The phylum Nanoarchaeota: present knowledge and future perspective of a unique form of life. Res. Microbiol., 154, 165-171.

Huynh, H., Verneau, J., Levasseur, A., Drancourt, M., Aboudharam, G. (2015). Bacteria and archaea paleomicrobiology of the dental calculus: a review. Mol. Oral Microbiol. DOI: 10.1111/omi.12118.

Jachlewski, S., Jachlewski, W., Linne, U., Brasen, C., Wingender, J., Siebers, B. (2015). Isolation of extracellular polymeric substances from biofilms of the thermoacidophilic archaeon Sulfolobus acidocaldarius. Front. Bioeng. Biotechnol. DOI: 10.3389/fbioe.2015.00123.

Jaworski, A., Serwecińska, L., Stączek, P. (2005). Quorum sensing - communication cells in the bacterial population with the participation of chemical signaling molecules (in Polish). Post. Biol. Kom., 32, 231-256. 
Kaur, A., Capalash, N., Sharma, P. (2018). Quorum sensing in thermophiles: prevelance of autoinducer-2 system. BMC Microbiol. DOI: 10.1186/s12866-018-1204-x.

Koch, M., Rudolph, C., Moissl, C., Huber, R. (2006). A cold-loving crenarchaeon is a substantial part of a novel microbial community in cold sulphidic marsh water. FEMS Microbiol. Ecol., 57, 55-66.

Koerdt, A., Godake, J., Berger, J., Thormann, K., Albers, S. (2010). Cranarchaeal biofilm formation under extreme conditions. PLoS ONE. DOI: 10.1371/journal.pone.0014104.

Koerdt, A., Jachlewski, S., Ghosh, A., Wingender, J., Siebers, B., Albers, S. (2012). Complementation of Sulfolobus soplfataricus PBL2025 with an $\alpha$-mannosidase: effects on surface attachment and biofilm formation. Extremophiles, 16, 115-125.

Koerdt, A., Orell, A., Pham, T.K., Mukherjee, J., Wlodkowski, A., Karunakaran, E., Biggs, C.A., Wright, P.C., Albers, S.-V. (2011). Macromolecular fingerprinting of Sulfolobus species in biofilm: a transcriptomic and proteomic approach combined with spectroscopic analysis. J. Proteome Res., 10, 4105-4119.

Lapaglia, C., Hartzell, P. (1997). Stress-induced production of biofilm in the hypothermophile Archaeoglobus fulgidus. Appl. Environ. Microbiol., 63, 3158-3163.

Lassak, K., Neiner, T., Ghosh, A., Klingl, A., Wirth, R., Albers, S. (2012). Molecular analysis of crenarchaeal flagellum. Mol. Microbiol., 83, 110-124.

Li, L., Zheng, M., Ma, H., Gong, S., Ai, G., Liu, X., Li, J., Wang, K., Dong, X. (2015). Significant performance enhancement of a UASB reactor by using acyl homoserine lactones to facilitate the long filaments of Methanosaeta harundinacea 6Ac. Appl. Microbiol. Biotechnol., 99, 6471-6480.

Matarazzo, F., Ribeiro, A., Faveri, M., Taddei, C., Martinez, M., Mayer, M. (2012). The domain Archaea in human muscosal surfaces. Clin. Microbiol. Infect., 18, 834-840.

Mayerhofer, L., Macario, A., Conway de Macario, E. (1992). Lamina, a novel multicellular form of Methanosarcina mazei S-6. J. Bacteriol., 174, 309-314.

Megaw, J., Gilmore, B.F. (2017). Archaeal persisters: persister cell formation as a stress response in Haloferax volcanii. Front Microbiol. DOI: 10.3389/fmicb.2017.

Moissl, C., Rachel, R., Briegel, A., Engelhardt, H., Huber, R. (2005). The unique structure of archeal 'hami', highly comlex cell appendages with nano-grappling hooks. Mol. Microbiol., 56, 361-370.

Montgomery, K., Charlesworth, J., LeBard, R., Visscher, P., Burns, B. (2013). Quorum sensing in extreme environments. Life, 3, 131-148.

Myszka, K., Czaczak, K. (2010). Quorum sensing mechanism as a factor regulating virulence of Gramnegative bacteria (in Polish). Post. Hig. Med. Dośw., 64, 582-589.

Ng, S., Zolghadr, B., Driessen, A., Albers, S., Jarrell, K. (2008). Cell surface structures of Archaea. J. Bacteriol., 190, 6039-6047.

Nichols, J.D., Johnson, M.R., Chou, C.-J., Kelly, R.M. (2009). Temperature, not LuxS, mediates AI-2 formation in hydrothermal habitats. FEMS Microbial Ecol., 68, 173-181.

Nickell, S., Hegerl, R., Baumeister, W., Rachel, R. (2003). Pyrodictium cannulae enter the periplasmic space but do not enter the cytoplasm, as revealed by cryo-electron tomography. J. Struct. Biol., 141, $34-42$.

Niederberger, T., Götze, D., McDonald, I., Ronimus, R., Morgan, H. (2006). Ignisphaera aggregans gen. nov., a novel hyperthermophilic crenarchaeote isolated from hot springs in Rotorua and Tokaanu, New Zealand. Int. J. Syst. Evol. Microbiol., 56, 965-971.

Ozuolmez, D., Nea, H., Lever, M., Kjedsen, K., Jørgensen, B., Plugge, C. (2015). Methanogenic archaea and sulfate reducing bacteria co-cultured on acetate: teamwork or coexistence? Front Microbiol. DOI: $10.3389 /$ fmicb.2015.00492. 
Paggi, R.A., Madrid, E.A., D’Alessamdro, C.P., Cerletti, M., De Castro, R.E. (2010). Growth phase-dependent biosynthesis of Nep, a halolysin-like protease secreted by the alkaliphilic haloarchaeon Natrialba magadii. Lett. Appl. Microbiol., 51, 36-41.

Paggi, R.A., Martone, C., Fuqua, C., De Castro, R. (2003). Detection of quorum sensing signals in the haloalkaliphilic archaeon Natronococcus occultus. FEMS Microbiol. Lett., 221, 49-52.

Pohlschröder, M., Esquivel, R. (2015). Archaeal type IV pilli and their involvement in biofilm formation. Front Microbiol. DOI: 10.3389/fmicb.2015.00190.

Probst, A., Auerbach, A., Moissl-Eichinger, C. (2013). Archaea on human skin. PLoS ONE. DOI: 10.1371/ journal.pone.0065388.

Rajput, A., Gupta, A.K., Kumar, M. (2015). Prediction and analysis of quorum sensing peptides based on sequence features. PLoS ONE. DOI: 10.1371/journal.pone.0120066.

Rajput, A., Kaur, K., Kumar, M. (2016). SigMol: repertoire of quorum sensing signaling molecules in prokaryotes. Nucleic Acids Res. DOI: 10.1093/nar/gkv1076.

Raskin, L., Rittmann, B., Stahl, D. (1996). Competition and coexistence of sulfate-reducing and methanogenic populations in anaerobic biofilms. Appl. Environ. Microbiol., 62, 3847-3857.

Rinker, K., Kelly, R. (1996). Growth physiology of the hyperthermophilic archeon Thermococcus litoralis: development of a sulfur-free defined medium, characterization of an exopolysaccharide, and evidence of biofilm formation. Appl. Environ. Microbiol., 62, 4478-4485.

Schopf, S., Wanner, G., Rachel, R., Wirth, R. (2008). An archaeal bi-spacies biofilm formed by Pyrococcus furious and Methanopyrus kandlerii. Arch. Microbiol., 190, 371-377.

Schrenk, M., Kelley, D., Delaney, J., Baross, J. (2003). Incidence and diversity of microorganisms within the walls of an active deep-sea sulfide chimney. Appl. Environ. Microbiol., 69, 3580-3592.

Spang, A., Hatzenpichler, R., Brochier-Armanet, C., Rattei, T., Tischler, P., Spieck, E., Streit, W., Stahl, D., Wagner, M., Schleper, C. (2010). Distinct gene set in two different lineages of ammonia-oxidizing archaea supports the phylum Thaumarchaeota. Trends Microbiol., 8, 331-334.

Staley, J.T., Caetano-Anolles, G. (2018). Archaea-first and the co-evolutionary diversification of domains of life. BioEssays. DOI: 10.1002/bies.201800036.

Szabo, Z., Sani, M., Groeneveld, M., Zolghadr, B., Schelert, J., Alberts, S., Blum, P., Boekema, E., Driessen, A. (2007). Flagellar motility and structure in the hyperthermoacidophilic archeon Sulfolobus solfatericus. J. Bacteriol., 189, 4305-4309.

Tommonaro, G., Abbamondi, G., Iodice, C., Tait, K., De Rosa, S. (2012). Diketopiperazines produced by the halophilic archaeon, Haloterrigena hispanica, activate AHL bioreporters. Microbial Ecol., 63, 490-495.

Wang, Y., Yu, X., Ng, S., Jarrell, K., Egelman, E. (2008). The structure of an archaeal pilus. J. Mol. Biol., $381,456-466$.

Woese, C., Fox, G.E. (1977). Phylogenetic structure of the prokaryotic domain: the primary kingdoms. PNAS, 74, 5088-5090.

Zhang, G., Zhang, F., Ding, G., Li, J., Guo, X., Zhu, J., Zhou, L., Cai, S., Liu, X., Luo, Y., Zhang, G., Shi, W., Dong, X. (2012). Acyl homoserine lactone-based quorum sensing in a methanogenic archaeon. ISME Journal, 6, 1336-1344.

Zolghard, B., Klingl, A., Koerdt, A., Driessen, A., Rachel, R., Albers, S. (2010). Appendage-mediated surface adherence of Sulfolobus solftaricus. J. Bacteriol., 192, 104-110.

Cite as: Pawlikowska-Warych, M., Tokarz-Deptuła, B., Czupryńska, P., Deptuła, W. (2019). Biofilm and Quorum Sensing in Archaea. Acta Biologica, 26, 35-44. DOI: 10.18276/ab.2019.26-04. 